\title{
The Transmutation of the Symbolist Ethos: Mystical Anarchism and the Revolution of 1905
}

\author{
He [Chulkov] says to me, "mystical anarchism," I say to him, "non-acceptance \\ of the world, supra-individualism, mystical energism," and we understand \\ each other. ...
}

VIACHESLAV IVANOV

The Revolution of 1905 challenged the symbolists' belief that they could seclude themselves from the rest of society. Forced to reexamine their previous ideas, values, and attitudes, they developed new ideologies that took cognizance of the current crisis. Among the most prominent of the new ideologies was mystical anarchism, the doctrine of the symbolist writers Georgii Chulkov and Viacheslav Ivanov. Particularly attractive to the symbolists, mystical anarchism also influenced other artists and intellectuals; doctrines similar to it proliferated, and it engendered a polemic in which almost all the symbolists took part. ${ }^{1}$ Strikingly similar to the mystical anarchism of other periods of social upheaval, both in Russia and in the West, ${ }^{2}$ illuminating a facet of the little-known mystical and religious aspects of the Revolution of 1905 , and providing an example of the re-

1. V1. Orlov, Aleksandr Blok-Andrei Belyi; Perepiska (Moscow, 1940; reprint ed., Munich, 1969), pp. xxix-xxxiii; V1. Orlov, "Iz literaturnogo nasledstva Aleksandra Bloka," Literaturnoe nasledstvo, vol. 27-28 (Moscow, 1937; reprint ed., Vaduz, 1963), pp. 371-80; and James West, Russian Symbolism: A Study of Vyacheslav Ivanov and the Russian Symbolist Aesthetic (London, 1970), p. 134.

2. My discussion of mystical anarchism is limited to the theories of Chulkov and Ivanov. Similar doctrines, however, can be found in eras characterized by social upheaval and the breakdown of tradition. For medieval Western Europe, see Norman Cohn, The Pursuit of the Millenium: Millenarians and Mystical Anarchists of the Middle Ages, rev. and enl. ed. (Oxford, 1970), especially pp. 176-83; for seventeenth-century Russia, see Sergei Zenkovsky, Russkoe staroobriadchestvo [Russia's Old Believers] (Munich, 1970); for an interesting comparison to the role of eros (to be discussed in this essay), see Gershom Scholem, "Redemption Through Sin," The Messianic Idea in Judaism (New York, 1971), pp. 78-141. Recent Soviet émigrés report that documents expressing ideas similar to Chulkov and Ivanov's mystical anarchism circulate in samizdat form. The mystical anarchists' stress on eros and on music will remind American readers of certain traits of the youth culture of the 1960s.

An earlier version of this paper was read at the Annual Meeting of the American Association for the Advancement of Slavic Studies, Atlanta, Georgia, October, 1975. A Fordham University Faculty Fellowship made the research possible. 
sponse of apolitical writers and artists to revolutionary upheaval, Chulkov and Ivanov's doctrine merits closer study than it has so far received. ${ }^{3}$

Mystical anarchism constituted a transmutation of the symbolists' previous ideas, values, and attitudes, in combination with a new factor introduced by the revolution-the symbolists' desire to end their isolation from the people by creating a new culture and a new society in which alienation would be transcended and conflict resolved. ${ }^{4}$ The mystical anarchists reversed the pre-1905 symbolists' determination to keep art "pure" of political and social considerations, but retained their hostility to materialism, rationality, and bourgeois society, their emphasis on the "inner man," and their faith in the spiritually transforming powers of art and love. Extending the pre-1905 symbolist ideal of a "spiritual commune"5 of like-minded artists and intellectuals to encompass the entire society, mystical anarchists repudiated (in theory) their former individualism for the sake of sobornost' (originally a religious concept connoting a collective body in which the elements retain their individuality). The introspective and mystical orientation of early symbolism led many symbolists to a psychological and religious interpretation of the Revolution of 1905 ; it also caused them to direct their search for solutions into psychological and religious channels. (By "religious" they meant the sense of belonging to a greater whole, of feeling oneself an intrinsic part of all that exists.)

Mystical anarchists shared this general orientation. Dismayed by the fragmentation of Russian society and desiring social integration, they assumed that there was an underlying unity between all people and aimed to evoke and develop it by means of the "mystical experiences" of art and love. Advocating an entirely new kind of society, whose ties would be internal and voluntary, they demanded the elimination of all external restraints (including government, religious dogma, and traditional social customs) on the free expression of individuality. Mystical anarchism was a social and political version of Nietzsche's aesthetic individualism and of D. S. Merezhkovsky's "new religious consciousness," both popular among the symbolists since the turn of the century.

That mystical anarchism constituted a transmutation of the symbolist ethos, one induced by the Revolution of 1905, can be shown by explaining how elements of the pre-1905 symbolist ethos were absorbed and transformed in mystical anarchism and by relating mystical anarchism's development to the course of the revolution. Let us first, however, outline the basic tenets of mystical anarchism, indicating the stages of its development. Mystical anarchism will be developed as a state of mind as much as a doctrine, for it reflected an emotional revolt against the restraints inherent in reality and the chiliastic hopes the Revolution of 1905 aroused in many symbolists.

3. Brief descriptions of mystical anarchism can be found in Orlov, Perepiska, pp. xxixxxxiii; West, Russian Symbolism, pp. 132-34; James Woodward, Leonid Andreev (Oxford, 1969), pp. 126-44, passim; and Jutta Scherrer, Die Petersburger Religiös-Philosophischen Vereinigungen (Wiesbaden, 1973), pp. 159-67.

4. Strictly speaking, the symbolists' desire to end their isolation from the people was not new; it is one of the themes of D. S. Merezhkovsky's 1892 lecture, "On the Causes of the Decline and on the New Trends in Contemporary Russian Literature." But until 1905 the symbolists did not act upon it.

5. "Spiritual commune" is Merezhkovsky's expression. 
Mystical anarchism was born in July 1905 in a polemical exchange (in Voprosy zhizni) between Georgii Chulkov and Sergei Bulgakov. ${ }^{8}$ Though the doctrine is usually associated with Ivanov, Chulkov, who had been editor of Merezhkovsky's journal Novyi put', ${ }^{7}$ was actually its initiator and moving force. In Chulkov's first statement as a mystical anarchist, he opposed Bulgakov's search for specifically Christian solutions to social problems and eschewed the search for "new religious faith" that had occupied the members of the ReligiousPhilosophical Society of St. Petersburg. ${ }^{8}$ Instead, he advocated "new religious activity" and "new mystical experience." Objecting to the asceticism, humility, passivity, and otherworldliness preached by "Historical Christianity," Chulkov was especially critical of its "slave mentality" of sweetness and submission. "They [Christians] are bloodless," he charged, "they do not notice the blood which is spilled on the altar of the earth. War for them is delirium; revolution -a fairy tale; sexual passion-carnal imagination . . . feeling their powerlessness, they run from the world." 9

Advocating social activism, Chulkov, like Merezhkovsky, looked forward to a "new heaven and a new earth" and considered the Apocalypse, with its promise of renewal and rebirth, an affirmative statement. ${ }^{10}$ But while Merezhkorsky and other seekers of a "new religious consciousness" sought a new Christian dogma, Chulkov repudiated all dogma, proclaiming: "the struggle with dogmatism in religion, philosophy, morals, and politics-such is the slogan of mystical anarchism." ${ }^{11}$ Claiming that the struggle for the anarchistic ideal would lead not to "formless chaos, but to the overcoming of the world,"12 Chulkov then explained that the mystical anarchists would participate in the current "struggle for emancipation" but that their participation would be through the "mystical experiences" of art and orgiastic emotion and through their consciousness of the World Soul. ${ }^{13}$ While this may not seem particularly revolutionary in the political sense, to the

6. Georgii Chulkov, "Iz chastnoi perepiski, o misticheskom anarkhizme," Voprosy zhizni, 1905, no. 7, pp. 199-204. The polemic began with Chulkov's article "Poeziia V1. Solov'eva," Voprosy zhizni, 1905, no. 5, pp. 101-17. Bulgakov replied in the June issue, pp. 293-303; and then in the August issue, pp. 230-37. In dispute were Solov'ev's relation to the Orthodox church and Christian attitudes toward sex. "Poeziia Vl. Solov'eva" is reprinted in Georgii Chulkov, Sochineniia, vol. 5 (St. Petersburg, 1912) : 101-17.

7. Chulkov was appointed editor in August 1904 as a concession to the growing demand for political coverage. He in turn brought in N. Berdiaev and S. Bulgakov. The December 1904 issue of Novyi put' was the last; Voprosy zhizni succeeeded it.

8. Chulkov, "Iz chastnoi perepiski," pp. 199-200. For more on the Religious-Philosophical Society see B. G. Rosenthal, D. S. Merezhkovsky and the Silver Age: The Development of a Revolutionary Mentality (The Hague, 1975), pp. 80-151; and Jutta Scherrer, Die Petersburger Religiös-Philosophischen Vereinigungen.

9. Chulkov, "Iz chastnoi perepiski," p. 203.

10. Ibid. To use the term which Sidney Monas has applied to Mandelstam, Chulkov's apocalypse was also an apokatastasis, for he looked forward not only to the end but also to resurrection and renewal (see Sidney Monas, "Friends and Enemies of the Word," Texas Studies in Literature and Language, 17 [1975]: 373).

11. Chulkov, "Iz chastnoi perepiski," p. 202. The phrase is repeated in Chulkov's $O$ misticheskom anarkhizme (St. Petersburg, 1906, reprint ed., Letchworth, Eng., 1971), p. 43 (hereafter cited as $M A$ ).

12. Chulkov, "Iz chastnoi perepiski," p. 202.

13. Ibid. Chulkov insisted, however, that mystical anarchism was not a hedonistic doctrine and that struggle and sacrifice were necessary for spiritual transformation. 
mystic there is a direct link between inner experience and the cosmic process; internal struggle or inner activity, therefore, directly affects the course of events in the external world and in this particular case hastens the end of history and the apocalyptic transfiguration of the world. ${ }^{14}$

In September 1905, responding to the escalation of revolutionary activity, Chulkov argued that Russia was in the throes of an all-pervasive crisis, "both internal and external" and affecting all social strata. Not only institutions, he wrote, but the entire culture, was breaking up. Emphasizing the psychological and spiritual aspects of the crisis, he argued that a new culture must be created and that it must be free both from philistine (meshchanskii) willingness to compromise and cold ascetic indifference to this world. Never a liberal, Chulkov considered the constitutional order desired by liberals a threat to be overcome. Unless political freedom was accompanied by "social renewal," by an internal rebirth, he warned, Russia would become a mere copy of Western Europe. ${ }^{15}$ Previously, discussing religious renewal and church reform, he had stated, "unless society blazes up in holy love" only the external or institutional aspects of religion will be affected and "its heart will remain, as before, in paralysis."16 In the same revolutionary spirit he proclaimed that harmony within the limits of history is impossible. "The entire edifice of history must be burned ... not just with material fire but with spiritual fire ... [there must be a] complete renunciation of false bourgeois values." 17 That same month (September), and in the same journal (Voprosy zhizni), Chulkov's future collaborator, Viacheslav Ivanov, published his essay "The Crisis of Individualism"; in it he contended that "individualism is aristocratism, but aristocratism is obsolete,"18 and predicted the triumph of the more democratic principle of sobornost'. Ivanov and Chulkov were not yet allies, but both, recognizing the severity of the crisis, were groping, each from the perspective of his own Weltanschauung, for a solution. ${ }^{18}$

Mystical anarchism took clearer form in January 1906. That month Chulkov, hoping to influence the course of events, established his own publishing venture. He called it Fakely (Torches), symbol of mystical love, "eternally burning and never extinguished."20 The first publication, Fakely: Kniga pervaia, appeared early in the spring of $1906 .^{21}$ Containing poems, short stories, and dramas by

14. Ibid.; see pp. 201-2 for his statement that "outside the Apocalypse there cannot be a religious relation to the world" and p. 203 for his belief that the transformation of the world will begin in mystical experiences that will occur here on earth.

15. Georgii Chulkov, "Khronika kul'turnoi zhizni, teatr-studiia," Voprosy zhizni, 1905, no. 9 , pp. $245-46$.

16. Chulkov, "Poeziia V1. Solov'eva," Sochineniia, 5:115; and $M A$, pp. 38-39.

17. Georgii Chulkov, Gody stranstzii (Moscow, 1930), p. 74. At the time, Chulkovlike many symbolists, including the Merezhkovskys-felt closest to the anarchist Socialist Revolutionaries.

18. "Krizis individualizma" is reprinted in Viacheslav Ivanov, Po zvezdam (St. Petersburg, 1909), pp. 86-102 (hereafter cited as $P Z$ ). The statement quoted is on page 98 .

19. To use Ferdinand Tönnies's formulation, Ivanov and Chulkov desired Gemeinschaft (community), as distinct from Gesellschaft (society).

20. Chulkov, Sochineniia, $5: 155$; and $M A$, p. 39. Fakely was originally to be called Ogni. Chulkov and Ivanov had planned to found a theater, also to be called Fakely, but it never materialized.

21. The date is approximate, based on letters thanking Chulkov for the publication and on when reviews of it appeared; for the letters, see Chulkov, Gody stranstvii, pp. 341, 342, 369. 
Ivanov, Chulkov, Leonid Andreev, Andrei Belyi, Alexander Blok, Valerii Briusov, Ivan Bunin, Alexis Remizov, and Fedor Sologub, it encompassed a wide diversity of views. Chulkov wrote the introduction which proclaimed:

We do not strive for one voice. Only one thing draws us together, an irreconcilable hostility to power over man by external social norms. We believe in the meaning of life, in the search of humanity for complete freedom. We raise our torches in the name of the affirmation of the individual person and in the name of the free union of people based on love for the future transfiguration of the world. ${ }^{22}$

Not all the contributors agreed with even this broad statement, and when Fakely actually appeared it provoked a storm. ${ }^{23}$ Ivanov defended Fakely and his own collaboration with Chulkov in the May issue of Vesy, explaining: "He [Chulkov] says to me, 'mystical anarchism,' I say to him, 'non-acceptance of the world. supra-individualism, mystical energism,' and we understand each other and it seems to us that we have the common ideological ground for certain cultural work." 24 Obviously, clarification was needed; hence their booklet, On Mystical Anarchism, published the following June. ${ }^{25}$ Ivanov was renowned for his erudition; his Wednesday salons were a focal point of the St. Petersburg intelligentsia. ${ }^{26}$ His collaboration made mystical anarchism intellectually respectable.

On Mystical Anarchism represents the first, and most complete, theoretical statement of the mystical anarchists. Consisting of Ivanov's introductory essay,

22. "Predislovie," Fakely: Kniga pervaia (St. Petersburg, 1906), p. iii (hereafter cited as Fakely $I$ ).

23. Apparently the contributors did not see the contents of the entire issue before it was published. Two of the contributors, Briusov and Belyi, turned against Fakely for personal and philosophical reasons. Briusov, writing under a pen name (Avrelii), charged in Vesy, May 1906, pp. 54-58, that Fakely was not a true literary school and that by not accepting the world the mystical anarchists were throwing overboard the very materials of aesthetic creativity. For Briusov's review of $M A$ see $V$ esy, August 1906, pp. 43-47. Belyi wrote many articles and reviews on mystical anarchism, some under his real name, Boris Bugaev. For examples, see Vesy, August 1906, pp. 52-54; March 1907, pp. 57-69; May 1907, pp. 49-52; April 1908, pp. 38-42; October 1908, pp. 44-48; and also Zolotoe runo, July-AugustSeptember 1906 (combined issue), pp. 174-75; and January 1907, pp. 61-64. He charged that mystical anarchism existed "outside time and space," was amoral, was devoid of real theory (coming from Belyi this was a very serious charge), and was excessively individualistic because it imposed no real duties or obligations on its followers. Blok distanced himself from the mystical anarchists in June 1907 and again in August 1907 (see Chulkov, Gody stranstvii, p. 375) but still contributed to the third issue of Fakely, published in January 1908. See also Orlov, Perepiska, pp. xxx-xxxix; and his "Iz literaturnogo nasledstva Aleksandra Bloka," p. 378. For the personal aspects of the feud see Oleg Maslenikov, The Frenzied Poets (Berkeley, 1952), pp. 80, 180-86, 211-12.

24. Viacheslav Ivanov, "O Fakel'shchikakh i drugikh imenakh sobiratel'nykh," Vesy, May 1906, p. 54.

25. Again the date is approximate, based on letters (Chulkov, Gody stranstvii, p. 370) and on when reviews appeared. The 1971 reprint does not contain Viacheslav Ivanov's introductory essay "Ideia nepriiatiia mira," which is, however, included in $P Z$, pp. 103-22.

26. Carin Tschöpl, Vjačeslav Ivanov, Dichtung und Dichtungstheorie (Munich, 1968), p. 25. For a description of Ivanov's salons, see "The Tower," ibid., pp. 25-48. See also Margarita Woloschin [Voloshina], Die Grïne Schlange (Stuttgart, 1954), pp. 173-80; and S. K. Makovskii, "V. Ivanov v Rossii," Novyi zhurnal, 30 (1952) : 135-38. 
"On the Idea of the Non-Acceptance of the World," and four essays by Chulkov: "On the Paths to Freedom" (note the plural), "Dostoevsky and Revolution," "The Doctrine of the Divine Sophia," and "On the Affirmation of the Individual Person," the booklet propagated a doctrine based on two fundamental principles. The first was psychological, the conception of the person. The second was philosophical, the "non-acceptance of the world" or the refusal to accept necessity; closely linked to their chiliasm, it involved an unabashed irrationalism. Subsequent writings defended or further explored aspects of these two principles which will be explained below.

The psychological principle posited two dimensions to the human being: the empirical and the mystical. The "empirical person" is egoistic, self-assertive, antisocial, while the "mystical person" seeks unity with the universal (the World Soul) and asserts itself through love. ${ }^{27}$ Previous theorists of anarchism, Chulkov argued, had taken cognizance of only one of these two dimensions of the human being, and the consequent one-sidedness of their theories doomed them to failure. Max Stirner, for example, focused exclusively on the egoistic "empirical person," not realizing that affirmation of the "empirical person" as an end in himself was decadence. By "decadence" Chulkov meant the failure to overcome one's own singularity, the inability to love. He opposed decadence as a "psychological fact," not as a literary school. ${ }^{28}$ Pointing to Nietzsche's madness and to the suicide of Ibsen's heroine Hedda Gabler, whose ambition was insatiable, ${ }^{29}$ Chulkov argued that self-affirmation without love leads to a "fatal solitude," to self-destruction and death, and he faulted Bakunin, whom he otherwise admired, for failing to recognize that the "cement" that united individuals in the obshchiny, and $o b$ shchiny in the federation, was love. ${ }^{30}$ A free anarchistic society can be sustained, he argued, only when it is based on a mystical rather than a positivist world view, on love rather than egoism. Mystical anarchism fulfilled all human needs: the "empirical person's" need for freedom and the "mystical person's" need for love.

By love, Chulkov meant not the Christian agape but the pagan eros. Accusing Tolstoy of "dead moralism" and criticizing the cold impersonal love he preached, Chulkov regarded the "ecstatic content of orgiastic action" as a form of "mystical experience" and frequently cited Vladimir Solov'ev's famous essay, "The Meaning of Love" and the Hebrew Song of Songs. Elsewhere, Chulkov wrote of the "integration of humanity through love" and of love as the means to "social metamorphosis." Similarly, Ivanov, in his essay "On Love Which Dares" (Fakely II) treated eros as the common source of both aesthetics and religion and lamented their separation in the contemporary world. "In the structure of the new soul," he declared, "ethics will become erotics." And, in the same essay,

27. These concepts are explained in the first essay in $M A$, "Na putiakh svobody," pp. 3-7; and the last, "Ob utverzhdenii lichnosti," pp. 45-55 (pagination from 1971 reprint). An extensively revised version of the latter, containing much more social and political commentary, was included in Fakely: Kniga vtoraia (St. Petersburg, 1907), pp. 1-26 (hereafter cited as Fakely $I I$ ). Lichnost' is not synonymous with "individual" in the Western juridical sense; as Chulkov and Ivanov use the term, it means "person" and has a spiritual dimension, that is, it involves the soul as well as the body. Love is also discussed in Chulkov's essay "O sofianstve."

28. $M A$, p. 45 .

29. Georgii Chulkov, "Genrik Ibsen," in Sochineniia, 5:156-206.

30. $M A$, p. 5 . 
"Nourishing love, holy and passionate (strastnáia i strástnaia)-here is the basis of our religiosity." To him, the "sacred secret activity of sex" was the supreme act of affirmation. ${ }^{31}$

Just as Chulkov and Ivanov considered egoistic anarchism one-sided, so they objected to the type of mysticism which focuses on inner experience, passively submits to God's will, retreats from the world, and counsels humility. Stressing social activism, insisting on a new society dedicated to human values, and objecting to the self-abnegation esteemed by many mystics, Chulkov and Ivanov taught the "path" of the "ultimate affirmation of the individual person as an absolute principle." 32 Rejecting solitary meditation, they maintained that the mystical anarchist ideal requires a social context for its realization. Opposing chastity, they believed that sexual love is the divine means of overcoming isolation and egoism. But, Chulkov explained, affirming the principle of society does not imply the repudiation of individuality; on the contrary, it is the "consequence and deepening of its affirmation that leads us to true sociality, the freedom from power." 33 Like many of their fellow symbolists, the mystical anarchists considered emotional fulfillment, including sexual fulfillment, a prerequisite of the good society. Their psychological orientation was then quite radical; in 1906 Freud was not yet widely accepted-his sexual emphasis was considered scandalousand Jung had not yet published his theory of the "collective unconscious." The latter is actually antedated by Chulkov and Ivanov's belief in the existence of an underlying unity between all people.

The fundamental philosophic principle of mystical anarchism was its "nonacceptance of the world," its refusal to accept necessity; another form, Ivanov explained, of the age-old "struggle with God" (bogoborchestvo). ${ }^{34}$ Ivanov believed that the "struggle with God" had always constituted the essential dynamic of creative religious thought, for "without opposition to the Deity, there can be no mystical life in man [nothing to distinguish religious creativity and religious dynamism] from immovable dogma, moral commandments, and ceremonial prescriptions." 35 Tracing the "struggle with God" from ancient times to the present, Ivanov asserted that "mystical energism . . . arose in the womb of Judaism, became the soul of Christian culture, and is connected with our final expectations."36 Never explicitly defining "mystical energism," he clearly associated it with hope, like the hope of the Jews for an end to suffering and the rebuilding of Jerusalem. According to Ivanov, the Book of Job expressed the quintessence of the. Hebrew "struggle with God." Though the Jews struggled, they still accepted God's rule

31. For Ivanov, see "O liubvi derzaiushchei," Fakely $I I$, pp. 229-38, reprinted in $P Z$, pp. 369-76; see especially p. 372. See also his poem "Eros" (St. Petersburg, 1907). For Chulkov, see $M A$, especially pp. 35-43, where he discusses Solov'ev's "The Meaning of Love"; $M A$, pp. $6-7$ for his critique of Tolstoy's asceticism; and "Taina liubvi" in Fakely $I I$, pp. 209-28; the latter. includes a discussion of V. V. Rozanov's views on sex and the family. See also Chulkov, Gody stranstvii, p. 74.

32. $M A$, p. 4.

33. Ibid., p. 46. Note his distinction between "formal freedom" and "mystical freedom" on the same page.

34. $P Z$, p. 103. Bogoborchestwo is a calque of the Greek theomachia (English "theomachy").

35. Ibid.

36. Ibid., p. 105. 
over the world he had created; they obeyed his laws and never revolted against the laws of nature which he had established. Thus, though they were aware (unlike the ancient Greeks) of the dichotomy between freedom and necessity, their "almost juridical religion," based on the Covenant and the Law, precluded the idea of complete freedom. ${ }^{37}$ Only with Jesus Christ, who proclaimed "My Kingdom is not of this world," did complete freedom become possible. Ordering his followers not to love the law, nor anything else that is of this world, he caused them to seek a higher reality unlimited by the laws of God or the laws of nature. ${ }^{38}$ But, Ivanov continued, Christ did love the world. From this conflict, from the "irreconcilable no" and the "dazzling yes" which are both contained in Christianity, arose "mystical energism," the dynamic principle that has become the "moving force ... of our Christian souls." 38

Ivanov believed that "mystical energism," because it was striving toward a new world, was optimistic and affirmative; whereas Hindu and Buddhist nonacceptance, directed toward Nirvana, was entirely negative. $\mathrm{He}$ also insisted that the "struggle with God" had so deeply penetrated Christian culture that even atheists were affected by it. Ivan Karamazov's desire to "return the ticket," according to Ivanov, was motivated by the essentially Christian spirit of metaphysical revolt; Karamazov accepted God but not the world he had created. Following Karamazov, Ivanov announced that mystical anarchists would refuse to be the "slaves of necessity"; they would reject empirical reality, would deny the exclusive validity of the findings of modern science, and would submit neither to the laws of nature nor to the laws of God. Proclaiming the autonomy of human values, mystical anarchists would reject the world of the given in the name of the world as it should be. ${ }^{40}$

Maintaining that "love for the impossible is the principle of all religious thirst, of all creative fantasies," of all exploits and all ideals, of man's continual

37. Ibid., pp. 105-7. One of Ivanov's less known activities was translating Hebrew poetry with the aid of interlinear versions. Because he seems to have been familiar with Jewish culture, it is quite possible that he knew the famous Yiddish poem "A din Torah mit Gott" which expresses what Ivanov meant by the Hebrew "struggle with God." Written by a famous Hasidic rabbi, Levi Yitzhak of Berdichev (ca. 1740-1810), the text represents the Jewish people as the plaintiff and God as the defendant in a lawsuit under the laws of his own Torah. The song begins with Rabbi Yitzhak, the plaintiff's spokesman, addressing God familiarly, but as he launches into his bill of charges his indignation keeps mounting until he bursts out in a thunderous protest, "I shall not leave, I shall not budge from here till there will come an end [to Israel's suffering]." Nonetheless, he concludes his "brief" with the traditional ending of a Hebrew prayer, "magnified and sanctified be Thy great name."

38. Ibid., pp. 107-8. Ivanov ignored (in this essay) traditional Christianity's injunction to submit to the temporal powers in the hope of rewards after death. The Hebrew insistence that even kings are subject to the law can be a powerful curb on tyranny, but Ivanov's distaste for legalism caused him to overlook it. He, however, did contribute an essay, "Concerning the Ideology of the Jewish Question," to the anthology The Shield, edited by Maxim Gorky, Leonid Andreev, and Fedor Sologub (New York, 1917; reprint ed., Westport, Conn., 1975), pp. 125-40, in which he attacked "spiritual anti-Semitism," the belief that since the time of Christ, Jews have nothing positive to contribute.

39. $P Z$, p. 108.

40. Ibid., pp. 110 and 115. See also $M A$, pp. 49-50, for Chulkov's claim that the "empirical person" says "Thy will be done," but the "mystical person" struggles and refuses to accept. 
upward striving, Ivanov refused to limit his vision to the practical and realistic. "Anyone who accepts anything other than unconditional freedom," he said, "is not an anarchist." The true mystic realizes that what for reason is "impossible" is actually "authentic being, the one reality of the world." 41 Ivanov saw no contradiction between complete freedom of the person and total oneness. Considering reason virtually irrelevant and aiming to proceed "from the real to the more real" (a realibus ad realiora), Ivanov preached energism, activism, overcoming, artistic creativity, and orgiastic emotion, and affirmed the "dynamic self-definition of both the religious and the social principle: religion as life and inner experience, as prophecy and revelation, sociality-as that which will become sobornost ${ }^{. " 42}$

Proclaiming "love for the impossible," Ivanov was able to ignore practical difficulties and "realistic" or rational objections to his doctrine. Seeking "religious-social unity" through sobornost" (which he elsewhere defined as the "suprapersonal affirmation of ultimate freedom") ${ }^{43}$ he advocated "supra-individualism" (sverkh-individualizm) as a means of transcending isolation. "Supra-individualism" is virtually undefinable; Ivanov described it "broadly" as "individualism [that] recognizes itself as supra-individualism through mysticism" and "narrowly" as emanating from the "new tendencies in philosophic thought and artistic creativity." 44 Apparently, in the broad sense, "supra-individualism" refers to the individual's consciousness of being part of the "one reality of the world," that is, of transcending egoistic individualism; in the narrow sense it refers to the symbolists' attempt to bridge the gap between artist and people by externalizing and expressing, in art and music, the inner feelings common to all. In its inherent elusiveness, the concept "supra-individualism" recalls other virtually undefinable concepts of the mystical anarchists such as "mystical energism," "the non-acceptance of the world," and eros. The lack of precision in defining these concepts allowed the reader a wide latitude for his own interpretation but offered little guidance to the person who might actually attempt to use the vague concepts as guides to action.

Actually, Ivanov's primary concern was inner freedom, but the nuances of his rather involved and abstract theory were far less prominent than his claim that mystical anarchism was "outside 'Yes' or 'No," his rejection of norms and boundaries, his insistence on "religious adogmatism and social-legal amorphism," 45 and his prohibition on "binding the flowing energies of the infinitely self-liberating spirit" by external norms or "static forms" of any kind. ${ }^{46}$ Claiming that "formal morality" had collapsed in the nineteenth century, Ivanov stated that the "morality of conduct" had become the "morality of the passionate aspirations of the spirit," and he stressed eros and ecstasy. ${ }^{47}$ (Incidentally, Merezhkovsky's and Belyi's attacks on mystical anarchism stressed its amoralism.) Ivanov

41. $P Z$, p. 122.

42. Ibid., p. 119.

43. Ibid., p. 120 .

44. Ibid., p. 118; see also pp. 121-22 for Ivanov's reference to "supra-individualism" as the "overcoming of 'intimate art,' of the era of 'private creativity.'"

45. Ibid., p. 119.

46. Ibid., p. 120.

47. Ibid., p. 122. For an interesting aspect of Ivanov's (and his wife's) concept of eros, see Woloschin, Die Grïne Schlange, pp. 193-96, 217-18. 
recognized the nihilistic aspects of his theory but insisted that the "positive content" of mystical anarchism could not be decided in advance. For both Ivanov and Chulkov, mystical anarchism represented the "paths to freedom" and they refused to restrict their searchings in any way. ${ }^{48}$ Ivanov was educated in German. universities and was deeply influenced by idealism, while Chulkov disliked German philosophy and Kantian epistemology.99 Chulkov's interest in extrasensory phenomena tended toward the occult. But because Ivanov's essay appeared as the introduction to Chulkov's rather simple and literal formulations, Ivanov's nuances and qualifications tended to recede into the background. Mystical anarchism was widely interpreted to mean the literal emancipation of humanity from morality, government, and economics (the law of nature which decrees that people must work in order to eat).

Anarchism was only one aspect of the mystical anarchists' "struggle against necessity"; the fall of the state was intended to be their first victory, not their ultimate goal..$^{50}$ In $O n$ Mystical Anarchism, Chulkov had proclaimed:

We can be politiki, but only in the reverse sense; that is, we may participate in political life only to the degree that it is dynamic and revolutionary, only to the degree that it destroys state norms; and we may participate in the social struggle only to the degree that it destroys that social order which economically enslaves the individual person. But all political and social construction is inadmissible from our point of view ; our constructions are accomplished outside mechanical relations. ${ }^{51}$

By "mechanical relations," Chulkov meant any relationship that is external to the individual, that is not based on the needs of the "inner man," such as contractual or legal relationships. ${ }^{52}$

Expressing the chiliastic hopes which the Revolution of 1905 aroused in him, Chulkov hailed the "revolt of the human soul"s3 against constraints of any kind. He maintained that a "true revolution" is an entirely new beginning, an overthrowing of all "mechanical relations" in favor of a society ruled by love. "What norms and what laws have force in the area of love... love is first of all a miracle." ${ }^{54}$ By definition, according to Chulkov, to be in love means not to listen to reason, not to accept the world of the given, but to affirm the world of the miraculous. "Where the Holy Spirit [of love] is, there is freedom; there is a miracle." "55 But of all those who were not yet mystics, Chulkov regarded the socialists as closest to him because "they sincerely despise property."56 Most of

48. $P Z$, pp. 119-20. Note Ivanov's qualifying remark that mystical anarchism is "only a formal category of contemporary consciousness taken in its dynamic aspect" (p. 120).

49. Tschöpl, Vjačeslav Ivanov, p. 6; and Chulkov, Gody stranstvii, p. 63.

50. $M A$, p. 55.

51. Ibid., p. 54. Ivanov and Chulkov hoped to use the theater as a means to develop the new consciousness required for a society without law. For details see my "Theater as Church: The Vision of the Mystical Anarchists," forthcoming in Russian History.

52. $M A$, p. 55.

53. Ibid.

54. Chulkov, "Taina liubvi," p. 219.

55. Chulkov, Sochineniia, 5:211.

56. $M A$, p. 7 . 
all he hated the bourgeoisie and looked forward to the destruction of the society they had created.

He concluded On Mystical Anarchism with extensive quotations from a speech that Ibsen had given in 1887, thereby endorsing Ibsen's prediction that Europe was moving toward a "Third Kingdom" that would be neither pagan nor Christian. The ideas, morals, and institutions of contemporary society, Ibsen had said, have outlived their time and will be replaced by a yet unknown synthesis of poetry, religion, and philosophy. ${ }^{57}$ The "path" to this new emancipated and transfigured world, Chulkov believed, was

the path of the great uprising, the great mutiny. The social revolution which Europe will experience in the near future will be only a small prelude to the beautiful universal fire that will consume the old world. The old bourgeois order must be annihilated in order to clear the field for the final conflict; there, in a free socialist society, the mutinous spirit of the great Man-Messiah will arise, in order to lead humanity from mechanical structures to the miraculous embodiment of Eternal Wisdom. ${ }^{\mathbf{5 8}}$

Jesus Christ, Chulkov continued, was the greatest rebel who ever lived; his mutinous spirit lives on, leading humanity to the "Third Kingdom." whether the "Third Kingdom" would be "only Christian," Chulkov admitted, no one yet knew and he did not answer his own rhetorical question: "Are we [mystical anarchists] Christians?"60 $\mathrm{He}$ specified, however, that "power and freedom," "Caesar and the Galilean," would never be reconciled. ${ }^{81}$

In subsequent writings, the mystical anarchists elaborated on their fundamental psychological and philosophic principles. Fakely II (ca. April-May 1907) was entirely devoted to theoretical essays that treated the "antinomy of freedom and necessity" and the "problem of power as the basic question of sociology." 62 Declaring a "revolt against economics," mystical anarchists objected to Marxism because of its determinism and its materialism. Marxism, said A. A. Meier, a contributor to Fakely II, is not revolutionary; instead of abolishing the laws of nature, it aims to fulfill them. It will lead, therefore, not to freedom, not to the "miracle of self-affirmation outside the law," but to the "affirmation of a new law, a new order, a new reason in this world." ${ }^{83}$ Like other mystical anarchists, Meier desired a new world; his conception of freedom included freedom from economics, the ability to ignore the constraints imposed by the "dismal science." Unimpressed by the prosperity of the West, mystical anarchists condemned its (and

57. Ibid., p. 52.

58. Ibid., p. 53.

59. Ibid.

60. Ibid., p. 52.

61. Ibid., p. 53.

62. "Ot redaktsii," Fakely $I I$, p. v. The introduction stressed the diversity of views among its contributors: Chulkov, Ivanov, A. A. Meier, Lev Shestov, Sergei Gorodetskii, and others. It stated that mystical anarchism was not the complete answer but that it posed the direction in which the search for solutions to the contemporary crisis must proceed.

63. A. A. Meier, "Bakunin i Marks," ibid., p. 121. See also ibid., pp. 99 and 133; and Michael Barkun's discussion of antinomianism, in "Law and Social Revolution: Millenarianism and the Legal System," Lazv and Society Review, 6, no. 1 (August 1971): 112-41. 
Marx's) subservience to the laws of nature; they objected to the stress on economics, whether capitalist or socialist.

Fakely II also attacked those who would apply traditional Christian ideals to the solution of political problems. Reiterating his opposition to "Historical Christianity's" injunction to submit to God's will, and still opposed to reform, Chulkov insisted that Christianity and politics were mutually exclusive and accused the neo-idealists (Evgenii Trubetskoi, Sergei Bulgakov, and Nikolai Berdiaev) of making the same mistake made earlier by Solov'ev; it was impossible, Chulkov maintained, to separate what is God's from what is Caesar's. ${ }^{64}$ The constitutional monarchy advocated by the Christian Brotherhood ${ }^{\mathbf{6 5}}$ (a group that espoused a type of Christian socialism) and the tsarist autocracy defended by religious reactionaries were equally destructive of the "religious person" because they were based on power, not love.

The neo-idealists, furthermore, considered Christianity rational, whereas Chulkov rejected "all forms of rational expression." "Bs "Pure religion," he insisted, is "free of metaphysics" ;" its essence is in music, cult, and poetry (the means of communicating "inner experience"). Indeed, he defined mysticism itself as the "totality of psychic experiences based on the positive irrational experience that is taking place in the sphere of music." 68 Music was the symbol of the cosmic will for Schopenhauer, Nietzsche, and Wagner, with whose ideas Chulkov was familiar; in his usage, as in theirs, music connoted the irrational or nonrational, for it is associated with Dionysus rather than Apollo, with feeling rather than reason. Chulkov considered "every metaphysical system algebraic in the sense that it attempts to replace the living and complex with the dead and schematized." 69 Positing a close connection between music, love, and the eternal rhythms of life, he believed that music enabled the "mystical person" to express himself and to achieve a sense of unity and harmony with all that exists. ${ }^{70}$ Considering Christianity the affirmation of the suprarational, he expected miracles and hoped to replace all metaphysical systems with "some apotheosis of a formless Dionysian enthusiasm."71 Admitting that "from the positivist point of view . . mystical anarchism appears as the ravings of a maniac and even religious people recoil from the idea,"72 he realized that anyone whose philosophy

64. Chulkov, "Ob utverzhdenii lichnosti," Fakely $I I$, pp. 16-19.

65. Ibid., pp. 13-14, 16-19.

66. Chulkov's hostility to rationalism transcends the specific context in which the remark was made, a discussion of the God-man. He maintained that "our culture is characterized by differentiation and fragmentation, rationality and the triumph of the mechanical principle, but the person thirsts for unity and organic development" (ibid., p. 6).

67. $M A$, p. 37 .

68. Ibid., p. 3.

69. Ibid., p. 37.

70. Ibid., p. 47; Chulkov, Sochineniia, 5:211; and $P Z$, p. 218. Indeed, sabornost', the mystical anarchists' social ideal, is sometimes translated as "the choral principle." Through sobornost', conflict becomes harmony, the differentiated elements are integrated into a beautiful whole; in their formulation, the good society and music are virtually identical. For a discussion of the concept of music during the Silver Age, see Bernice Glatzer Rosenthal, "Revolution as Apocalypse: The Case of Bely," to be published in a volume entitled. Andrey Bely: A Critical Review, ed. Gerald Janecek (Spring 1978 publication date).

71. Chulkov, Gody stranstvii, p. 74.

72. Ibid. 
was based either on the "reason" of the scientific world view or on the Logos of Christian metaphysics would never take his own chiliastic views seriously.

Insisting that religion was a matter of feeling, Chulkov came to consider revolutionary activity to be religious in nature. Referring to the "tragic moment of revolutionary battle when the slaughter of the people is a holy sacrifice of history," he associated revolutionary martyrs with their Christian predecessors. ${ }^{73}$ Aiming to divorce religion from its association with reaction, as were many of his contemporaries, he denied any contradiction between religion and social progress. "I believe," he said in 1908, "that the religious spirit lives on in revolution and if this is so, the victories and sacrifices of the revolution are drawing us inevitably to the final emancipation."74 Implying that revolutionary fervor has an erotic component, he declared: "orgiastic emotion unites the spirit of revolution with the spirit of the crucified gods, with the spirit of Dionysus and Christ."75

The last issue of Fakely (January 1908) was only implicitly revolutionary. The editors' introduction stated that "art in itself is a powerful weapon in the struggle with spiritual meshchanstvo and stagnation"76 and they vowed to continue to strive toward their ideal goals, but their avowal lacked militance. The chiliastic edge was gone. The volume consisted of poems, short stories, and plays by Blok, Chulkov, Ivanov, Remizov, Zaitsev, and others which gave evidence of their authors' alienation from contemporary reality but which were not especially political.

Having outlined the basic tenets of mystical anarchism and indicated the stages of its development, let us return to the argument that mystical anarchism constituted a transmutation of the pre-1905 symbolist ethos, a transmutation induced by the Revolution of 1905 . After demonstrating the influence of Nietzsche and Merezhkovsky on mystical anarchism, ${ }^{77}$ we will relate the doctrine's development to the course of the Revolution of 1905.

Nietzsche, popular among the symbolists since the turn of the century, was the subject of Ivanov's essay "The Crisis of Individualism." Written to commemorate the three hundredth anniversary of Don Quixote, it focused on Thus Spake Zarathustra. "Individualism," Ivanov charged, "has killed the old gods and idolized the superman" and the superman has in turn killed individualism. "Individualism presumes the self-satisfied fullness of the human person but we fell in love with the superman. The taste for the superhuman killed in us the taste for the sovereign affirmation of the human in ourselves."78 Arguing that

73. $M A$, p. 42 .

74. Georgii Chulkov, "Pokryvalo Izidy," Sochineniia, 5:129.

75. Ibid. Note his remarks on the "theurgical significance of social struggle" and "the religious moment of revolutionary ascent" (p. 128).

76. "Predislovie," Fakely: Kniga tret'ia (St. Petersburg, 1908), p. v (hereafter cited as Fakely III).

77. This is not to imply that Nietzsche and Merezhkovsky were the sole influences on mystical anarchism. Solov'ev's and Dostoevsky's views were also important as were V. V. Rozanov's views on sex and the anarchistic ideals of $\mathrm{L}$. Tolstoy and Prince P. Kropotkin. Other non-Russians who influenced the formation of the mystical anarchist doctrine were Ibsen and Wagner. Nietzsche and Merezhkovsky, however, were the two most important influences.

78. $P Z$, pp. $95-96$. 
the concept of the superman ignores an entire spectrum of human emotional needs, Ivanov advanced a new concept, "the suprahuman," as distinct from the superman, maintaining that "the suprahuman" is a universal, even religious, concept of which all humanity will soon become aware. "Already," he said, "religious messianists, social messianists, messianists who struggle with God, all alike are living by the choral spirit and collective (sobornyi) hopes."79 Because of their inherent limitations, "the individualism of Faust and the adventurism of Wilhelm Meister end by turning to social activity, and the passionate commitment (pafos) of the person sobbing in the deep notes of the Ninth Symphony finds the resolution of the feverish agony of its torments . . in the triumph of sobornost ${ }^{\prime} . "{ }^{80}$ The age of the epic is gone, he declared (and presumably the age of the supermen who were its heroes): "may [that] of the choral dithyramb begin. . . . He who does not want to sing the choral song may withdraw from the circle, having covered his face with his hands. He may die, but to live in isolation is not possible." ${ }^{11}$ The essay marks Ivanov's response to the intensifying social crisis. Referring to discussions going on in symbolist circles, he maintained that contemporary individualism was "unconsciously and involuntarily" assimilating the traits of sobornost' (a "sign that in the laboratory of life some sort of synthesis . . . is being worked out") and "guessed" that the symbol of that synthesis would be "in a word, 'anarchy." "82 Though Ivanov qualified Nietzsche's individualism by maintaining that the "mystical person" can affirm himself only within society, he continued to emphasize the Nietzschean ideals of self-determination, self-affirmation, and the autonomy of human values, as did Chulkov.

From Nietzsche, also, stems the mystical anarchists' attack on traditional morality and aspects of their aesthetic and Dionysian orientation. Ivanov's statement that mystical anarchism was "outside 'Yes' or 'No,'” outside norms and boundaries, recalls Nietzsche's injunction to break the old "tablets of values"; Chulkov's search for "new experience on the other side of good and evil"8s clearly connotes Nietzsche's Beyond Good and Evil. Sensitized by Nietzsche to the lure of power for its own sake, ${ }^{84}$ Ivanov and Chulkov repudiated the "lust for power and dominion"; their apotheosis of "powerlessness" constituted the inverse of Nietzsche's "will to power." 85 Their ideal was that all persons, not just the strong, should be free to develop their individuality. Their call for energy, activism, daring, struggle, and artistic creativity was Nietzschean in tone; their affirmation of eros and Ivanov's proclamation of "supra-individualism" recalled

79. Ibid., p. 96.

80. Ibid., p. 99.

81. Ibid., pp. $99-100$.

82. Ibid., p. 100.

83. Chulkov, Sochineniia, 5:126.

84. The prevailing American interpretation of Nietzsche's "will to power" treats it as creative power, the power of the artist, implying spiritual struggle and a stern mastery over the self. For a contrary view, see Connor Cruise O'Brien, "The Gentle Nietzscheans," in New York Review of Books, November 5, 1970, pp. 12-16. O'Brien argues that authoritarian politics is implicit in the transvaluation of Christian values advocated by Nietzsche. Let us note simply that Ivanov and Chulkov did recognize the dangerous ambiguities inherent in Nietzsche's concept.

85. $P Z$, pp. 98 and 117. Note the Nietzschean formulation "satiety or freedom" (ibid., p. 100). 
Nietzsche's emphasis on sensuality and self-overcoming in his discussions of the functions of the Dionysian rites. ${ }^{86}$ Finally, like Nietzsche, Ivanov and Chulkov focused on the perennial problems of the human condition: love and death, tragedy and suffering. Their epistemology, especially Ivanov's, assumed the phenomenal nature of reality and stressed the nonrational aspects of existence and being ; it was similar to, though not identical with, Nietzsche's. ${ }^{87}$

But the mystical anarchists' frame of reference and much of their terminology stems from D. S. Merezhkovsky, popularizer of Nietzsche in Russia in the nineties and propagator of a "new religious consciousness" in the early years of the twentieth century. "Historical Christianity" (referring to the alleged perversion or obscuring of Christ's message by the official churches) is his term, and Chulkov, especially, was influenced by Merezhkovsky's interpretation of Christianity. Chulkov's intellectual debt to Merezhkovsky is obvious in his essays on Dostoevsky, Solov'ev, and Ibsen. ${ }^{88}$ Ibsen's "Third Kingdom" is similar to Merezhkovsky's "Third Revelation" (in that both foresee some sort of new dispensation but cannot predict its content ${ }^{89}$ ) and Chulkov credited Merezhkovsky with being among the first symbolists to turn to "sociality."90 Ivanov's apocalypticism was less literal than Chulkov's. Not really a revolutionary, Ivanov was closer to Solov'ev than he was to Merezhkovsky. Like Merezhkovsky, however, Solov'ev stressed the divine roles of art and sex and prophesied the emergence of a new type of human being, the "God-man" ( similar in some respects to Ivanov's concept of "the suprahuman").

In 1900, Solov'ev proclaimed the imminence of the Final Conflict; at about the same time, Merezhkovsky, looking for clues on how to synthesize Nietzscheanism and Christianity, became convinced that they could be found in the Revelation of. Saint John. Ivanov was definitely familiar with Merezhkovsky's thought. Merezhkovsky's famous essay, "On the Hellenic Religion of the Suffer-

86. Nietzsche discusses the Dionysian rites in The Birth of Tragedy. For Ivanov and Chulkov's attempt to re-create the Dionysian theater see my forthcoming article, "Theater as Church: The Vision of the Mystical Anarchists." Their solution to the fragmentation and conflict of contemporary society was, in many respects, a Dionysian solution.

87. Nietzsche's concept of the "eternal return" is cyclical, whereas the mystical anarchists, especially Chulkov, thought in more linear terms, positing the end of this world and the beginning of the new world. At that point, however, history ends and a new cycle begins. See Ivanov's remark that "the moment is the brother of eternity," $P Z$, p. 96. Ivanov believed that an ultimate truth can be found beyond the Dionysian flux; for Nietzsche, there was no truth, only illusions that masked the terror of the abyss.

88. In his essay "Dostoevskii i revoliutsiia," Chulkov stated that many critics have written about Dostoevsky, but none has come as close to the central point of his world view as Merezhkovsky ( $M A$, pp. 9-10). Compare Chulkov's interpretation of Solov'ev ( $M A$, especially p. 41), with Merezhkovsky's concept of "holy flesh" (Rosenthal, D. S. Merezhkoysky, pp. 106-14). Like Merezhkovsky, Chulkov believed that "Historical Christianity" was coming to an end and, also like Merezhkovsky, he admired Tolstoy's courage in defying the temporal powers but objected to his call for chastity. Chulkov's charge that Ibsen's type of individualism leads to a "fatal solitude" recalls Merezhkovsky's essay on Ibsen in Vechnye sputniki (in D. S. Merezhkovskii, Polnoe sobranie sochinenii, vol. 17 [St. Petersburg, 1914], especially pp. 190-94). See also Chulkov, Gody stranstvii, pp. 73 and 77 . Chulkov and Ivanov met at the home of the Merezhkovskys.

89. According to Merezhkovsky, a "Third Revelation" or "Third Testament" will complete the message of the Old and New Testaments.

90. Chulkov, Gody stranstvii, p. 133. 
ing God," was serialized in Novyi put', and the two men also moved in the same circles. Indeed, the mystical anarchists' definition of the issues-the problems their ideology aimed to solve-was deeply influenced by Merezhkovsky's choice of discussion topics at the meetings of the Religious-Philosophical Society: religion and life, individual and society, sex and Christianity, authority and freedom. But Merezhkovsky's "new religious consciousness" involved seeking a specifically Christian "new faith." The mystical anarchists, on the other hand, sought a broader "religious synthesis of life" activity" and "mystical experience" on a kind of pantheism in which the relation of Christ, Dionysus, and the World Soul was not at all clear. ${ }^{92}$ Nonetheless, like Merezhkovsky, and unlike Nietzsche, they were convinced that the problems of their time required a religious solution. And, like Merezhkovsky, they were persuaded by the events of $1904-5$ that the artist must rejoin society. Sharing Merezhkovsky's chiliastic expectations, they too believed that the old world was ending.

It was the intensifying revolutionary activity, highlighting the symbolists' inability to influence events (a disturbing thought for admirers of Nietzsche who scorned passivity), that led the mystical anarchists to question their previous ideas and to attempt to incorporate their individualism into a social framework. Ivanov, as early as March 1904, challenged the symbolists' isolation from the people, arguing the need to fathom the "forbidden mysteries of the folk soul." $\mathrm{He}$ continued to advocate reconciliation and social unity all during 1904 and $1905,{ }^{94}$ and these attitudes came to be shared by other symbolists. The realization that the old order was ending, plus the belief that symbolists could create a new culture and a new society dedicated to their own values, proved to be a powerful stimulus to the development of new ideologies.

James Woodward has suggested that mystical anarchism was an escapist ideology, the product of despair. "The collapse of the hopes of external freedom," he writes, "accentuated the need for a more profound and durable inner freedom." This may well apply to Leonid Andreev, the subject of Woodward's study, who was associated with the mystical anarchists for a short time, but it does not apply to Chulkov or Ivanov, the formulators of the ideology. "External freedom" applies to the "empirical person"; it implies the definition of his rights vis-à-vis other individuals and the state. Chulkov and Ivanov never esteemed this type of freedom; they considered it "formal" freedom, as distinct from "mystical" or real freedom. At no point did they believe that sobornost' could be achieved through a restructuring of the "mechanical" institutions of the political

91. $P Z$, p. 227.

92. Belyi, reacting to this vagueness, pointedly asked rehich God would be worshipped in the mystery theater that Ivanov and Chulkov were planning-Apollo, Dionysus, Christ, Muhammad, Buddha, or "Satan himself" (see Vesy, October 1908, p. 47). Their vagueness recalls Nietzsche, who realized the problems which the "death of God" would pose for humanity but failed to offer an unambiguous solution.

93. PZ, p. 242. This is from his essay "Poet i chern'," first published in Vesy, March 1904.

94. See Ivanov's essays, "Kop'e Afiny" (October 1904) and "Novye maski" (July 1904), for other examples of his desire to reconcile the artist and the people and to find a new basis for social unity ( $P Z$, pp. 43-54 and 54-64 respectively).

95. Woodward, Leonid Andreev, p. 127. 
order. To Chulkov, parliaments were the epitome of meshchanstvo and he objected to the compromise and conciliation which they required. ${ }^{9 \theta}$ To Ivanov, the "choral voice of the obshchina" represented the "genuine referendum of the people's true will" ; $; 7$ he considered political parties divisive.

Thus, the mystical anarchists cannot be said to have despaired at the inconclusive results of the Revolution of 1905 and at its failure to bring a fully operative version of a constitution and a parliament into being in Russia. Sharing Nietzsche's and Merezhkovsky's contempt for bourgeois society and its institutions, they may even have been encouraged. They hailed political revolution because they believed that the destruction of the state would clear the field for a new society based on freedom, creativity, and love. As for the origins and development of the doctrine, Woodward's timing is off. Rather than being the product of despair, mystical anarchism was the product of hope-the old hope of Russian radicals that the bourgeois stage of development could be avoided. Optimism sparked its birth and sustained its development.

Mystical anarchism, born in July 1905, was Chulkov's response to months of intense revolutionary activity. His first statement of the doctrine appeared before the Bulygin rescript of August and well before revolutionary activity reached a crescendo in October. His second statement, made in September, marked his reaction to the still escalating revolutionary activity and manifested his belief that a new culture could be created. Ivanov's "The Crisis of Individualism" appeared the same month. Though Chulkov and Ivanov realized that the transition to the new era would entail suffering, sacrifice, and inner turmoil, they both faced the future with hope. As for the liberal and radical revolutionaries who desired the "external freedoms" guaranteed by constitutions and parliaments, their hopes were still mounting.

Mystical anarchism became an ideology and exerted the most influence in the period of optimism that followed the promulgation of the October Manifesto. Even though the tsarist government backed down on its promises from November 1905 on, and even though the December 1905 uprising was brutally suppressed, the mystical anarchists (and other radicals), lacking our hindsight, remained optimistic. Fakely $I$ appeared in March or early April 1906, shortly before the first Duma convened. Its editors proclaimed that "to live this way is impossible,"98 but fully expected far-reaching change. The first Duma met on April 27, 1906 (O.S.) ; it was an opposition Duma, for government-backed candidates had been defeated. Socialist Revolutionaries and Social Democrats, hoping to achieve better results outside the Duma, boycotted the electoral campaign. In the seventythree days the Duma was in session, revolutionary agitation revived, along with agrarian riots and terrorist acts. On Mystical Anarchism appeared early that summer. The first Duma was dissolved on July 8-9, 1906 (O.S.). Within a week after its dissolution, Stolypin, the new minister, was confronted by revolutionary activity so intense that he proclaimed a state of emergency. ${ }^{99}$ The second Duma,

96. On Chulkov's scorn for half-measures, see Fakely $I I$, p. 14; and Voprosy zhizni, 1905, no. 9 , p. 246.

97. $P Z$, p. 219.

98. "Predislovie," Fakely $I$, p. iii.

99. Richard Charques, The Twilight of Imperial Russia (Oxford, 1958), pp. 161-62, points to "renewed rioting in the armed forces" (in Sveaborg, Kronstadt, and on board a 
also an opposition Duma, was even more radical than the first because of the participation of S.R.'s and S.D.'s. It convened on February 20, 1907 (O.S.) ; it was still in session when Fakely $I I$ appeared. Even then, mystical anarchists believed, along with many S.R.'s and S.D.'s, that radical social transformations were still forthcoming. Chulkov, for example, demanded the removal of all economic as well as political barriers to self-expression, announced his "irreconcilable and revolutionary relation to every form of government and to the institution of property," and proclaimed "we are where the revolution is."100 Ivanov regarded anarchism as a "metaphysical idea" and defined individualism as a "phenomenon of the subjective consciousness." 101 Yet he did not deny his ally's maximalist demands and apparently endorsed Chulkov's proclamation that "we are not only destroyers, we are also creators . . . our creativity is the creativity of love."102 Ivanov's own contribution, "On Love Which Dares,"103 apotheosized eros and masculine daring ; even he, it seems, was carried away by the chiliastic expectations aroused by the revolution.

The new electoral law of June 1907, however, forced the revolutionary leaders to acknowledge defeat; many, including Lenin, went into exile. Fakely III (January 1908) reflected the deflated hopes of its editors. There is, for example, a defensive air to the statement that "we will continue to defend our views," 104 and the anthology itself, despite the inclusion of works by leading modernists, provoked little reaction.

With the defeat of the revolutionary movement, mystical anarchism lost its luster and its leaders began seeking quite different solutions to the problems of their time. They had always been more concerned with the socially and psychologically integrating functions of religion (the "religious-social") than with (finding) religious truth. By 1908 the social aspects of their ideology overwhelmed its individualistic aspects. Chulkov, quoting Nietzsche's statement that "man is a bridge and not a goal," stressed Nietzsche's concept of self-transcendence and maintained that "every truly religious act is an overcoming of individualism." 105 Retracting his earlier emphasis on eros, he insisted that he had never meant to sanction "orgies, erotic communes, or demonic cults."106 Moving closer to the Marxists, he argued that without a change in the economic circumstances of life, spiritual renewal is impossible. ${ }^{107}$ Ivanov, chagrined by the pornography

battleship of the Baltic fleet), to the revival of terrorism, and to another attempt at a general strike in Moscow as evidence that "the possibility of a second venture in armed insurrection there could not yet be dismissed. And then followed a spate of Socialist Revolutionary murders and the first wave of terror of the extreme Socialist Revolutionary faction, the Maximalists." See also ibid., pp. 145-48, 176, and, for the effects of university autonomy, p. 123.

100. Chulkov, "Ob utverzhdenii lichnosti," Fakely $I I$, p. 25.

101. $P Z$, pp. 99 and 118 ; see also p. 101.

102. Chulkov, "Ob utverzhdenii lichnosti," Fakely $I I$, p. 25.

103. Ivanov's article is on pp. 229-38.

104. Fakely $I I I$, p. v.

105. Chulkov, "Pokryvalo Izidy," pp. 125 and 127.

106. Georgii Chulkov, "Razoblachennaia magiia," Zolotoe runo, 1908, no. 1, p. 63.

107. Georgii Chulkov, "Printsipy teatra budushchego," in Teatr, Kniga o novom teatre, ed. G. Chulkov (St. Petersburg, 1908), pp. 205-6. 
and decadence around him and subdued by the death of his wife the year before, turned more and more to a type of Christian existentialism. "Dionysus in Russia is dangerous," he said, and when he spoke of "self-affirmation," he usually coupled it with the adjective "demonic." 108 Their paths continued to diverge. By 1917 Chulkov hailed the Bolshevik Revolution; Ivanov at first was mildly sympathetic but quickly turned against it. ${ }^{108}$

Despite its brief life, mystical anarchism, or anarchism that purported to combine individual freedom and social integration through the mystical experiences of art and love, is important as an example of a state of mind that was fairly widespread. The importance of Ivanov's salon as a focal point of the St. Petersburg intelligentsia has already been mentioned. With the advent of university autonomy, Chulkov and Ivanov lectured to large audiences of students and young workers. Doctrines similar to mystical anarchism also proliferated during these years: Gofman's "collective individualism," Merezhkovsky's "religious sociality," Minskii's "meonism." In different ways, they too aimed to remove the power of man over man and to provide for social unity through common beliefs 110 and through love. Even some Marxists developed a type of secular religion ; Lunacharskii's and Gorky's "God-Building" was one example. ${ }^{111}$ Bal'mont's "Firebird" and Scriabin's "Mysterium" demonstrated the appeal to the artistic imagination of doctrines in which a new society of freedom and love arises phoenix-like from the fires of revolution. Dmitrii Filosofov, Merezhkovsky's associate, in a very critical review of On Mystical Anarchism, still credited it with being a "psychological document of great importance" whose ideas are "in the air" and have "captured the contemporary soul."112

Indeed, the very vagueness of mystical anarchism, while a fault from a philosophical point of view, was probably an asset, for it enabled audiences to construct their personal fantasies of a utopia of sensual gratification. The appeal of a doctrine, moreover, which holds sex and art to be the divinely sanctioned means to social renewal and psychological integration, would seem to require no further explanation. Lunacharskii conceded in 1906 the great interest in anarchism and in 1908 contributed an essay to Chulkov's anthology Teatr in which he argued for socialism as the liberator of the individual person. ${ }^{113}$ A. Smirnov, also

108. $P Z$, p. 360 ; see also ibid., p. 307 , where Ivanov contrasts choral activity with "demonic self-assertion," and p. 325 for his statement that "critical culture is the culture of the sons of Cain."

109. Chulkov remained in Russia until his death in 1939. Ivanov emigrated in 1924, settled in Rome, and converted to Roman Catholicism. He contributed to the now famous symposium Iz glubiny.

110. One of the aims of the Dionysian theater which Ivanov and Chulkov envisioned was to develop new myths.

111. See George L. Kline, Religious and Anti-Religious Thought in Russia (Chicago, 1968), pp. 103-26.

112. Zolotoe runo, 1906 , no. 10 , p. 59 . On page 64 , Filosofov argued that individual religious life is impossible without organized religion. Like Merezhkovsky he was seeking a new Christian dogma and objected to the mystical anarchists' amoralism.

113. Woodward, Leonid Andreev, p. 144. For Lunacharskii's essay "Sotsializm i iskusstvo," see G. Chulkov, ed., Teatr, pp. 7-40. But also see his critique of the symbolist aesthetics, "T'ma," in Literaturnyi raspad (St. Petersburg, 1908), pp. 147-72. 
recognizing in 1906 the popularity of anarchism, attributed this popularity to the "unbearable conditions of life" which make "emotional anarchism" (which would seem to include mystical anarchism) a "natural, even inevitable fact." 114

The course of mystical anarchism registered the rise and fall of the chiliastic hopes which the Revolution of 1905 engendered in many symbolists. ${ }^{115}$ Though Ivanov and Chulkov spoke of tragedy, suffering, and sacrifice, ${ }^{116}$ their tone was basically optimistic. They saw no need to compromise, to accept half-measures, or to settle for the limited freedom of a constitutional monarchy because they believed that a new era of complete freedom and all-encompassing love was at hand. Thus they demanded, and thought feasible, the elimination of all restraints on the free expression of individuality and based their society of the future on the "mystical person" who asserts himself through love and creativity. ${ }^{117}$ Their optimistic faith that the tremendous gulf between the artist and the people could be bridged, that sobornost' could actually be realized, that they could refuse to accept the limits imposed by reality, was sustained by revolutionary upheaval. When these hopes faded, with the stabilization of Russian society around the summer of 1907, so did the appeal of mystical anarchism. In 1908 fewer articles on mystical anarchism appeared in the journals; in 1909, fewer still. By 1910 the symbolists were preoccupied with other issues, and in 1911 Belyi, one of mystical anarchism's most bitter opponents, announced that the heated polemics on the subject already belonged to the past. ${ }^{118}$

114. As quoted by Woodward, in Leonid Andreev, p. 144.

115. See West, Russian Symbolism, p. 133, who alludes to an article by Filosofov declaring "that all symbolists and decadents were sufficiently alike to be classed together as mystical anarchists and that their attempts to differentiate amongst themselves were a purely domẹstic affair."

116. Voprosy zhizni, 1905, no. 7, p. 203; $M A$, pp. 43-44; and $P Z$, p. 99.

117. Their emphasis on love recalls the "make love not war" slogan of the 1960 s, a radical derivation of Freud's views on the relation of sexual frustration and aggression. Never really an optimist, Freud became even less sanguine about the possibility of curbing human aggressiveness after 1914; his Beyond the Pleasure Principle, which asserted the existence of a "death wish" and of a perennial struggle between Eros and Thanatos, appeared in 1920.

118. Andrei Belyi, "Vmesto predisloviia," Arabeski (Moscow, 1911; reprint ed., Munich; 1963), p. ii. 